\title{
Policy
}

\section{Challenges and opportunities in inheritance rights in Rwanda}

\section{Summary}

- Rwanda's laws provide opportunities for gender equity by granting equal inheritance rights to sons and daughters and protection of a surviving spouse's and children's rights to property. However, customary systems continue to govern over family and land matters and often discriminate against women's direct rights to property and inheritance.

- The majority of adult women in Rwanda have no legal protection of their rights to property and inheritance because there is no legal recognition of consensual cohabiting and polygamous unions (unregistered marriages).

- The registered consent of all individuals with rights in land prior to any land transfers, as required by Rwanda's land laws, is an opportunity to protect the land rights of women and children. Recent land registration exercises have provided opportunities to document all individuals with interests in land, but these are challenged with how to determine the rights of women in cohabiting unions without registered marriages, resulting in cases of de facto policymaking.

- With 80 percent of existing land plots measuring less than one hectare, and a law that states no division of land of less than a hectare, practical challenges exist in realising the distribution of land and immovable property among people with rights to inherit.

- Local dispute resolution bodies provide access to conflict mediation, yet the outcomes of these bodies (e.g. regarding gender equity) are not systematically monitored or analysed.

- Monitoring and enforcement of inheritance distributions need to be a focused effort, especially on behalf of people with limited social, economic and political influence, such as minor children whose inherited property is kept under appointed guardianship until they reach age of majority.

\section{Introduction}

Inheritance is a major means for the transfer, or exclusion from the transfer, of people's accumulated physical capital. The transfer of physical assets from the parent to the child generation can provide the start-up material for the younger generation's more independent future livelihoods and economic productivity (Fafchamps and Quisumbing, 2005). However, exclusion from assets inheritance can exacerbate vulnerability to chronic poverty and the intergenerational transmission of poverty (Bird et al., 2004).
In some countries, inheritance laws and customary practices can exclude individuals, particularly women and orphaned children, from inheriting the property (including land, housing and other productive resources) that they had access to while their husbands or fathers were alive (see Cooper, 2008 and 2010). This has been linked to economic decline and poverty traps (Bird et al., 2004; Human Rights Watch, 2003; Strickland, 2004). Reforming statutory and customary systems can address gender discrimination in inheritance practices 
(Benschop and Sait, 2006; Bird et al., 2004; Davies, 2005; Mutangadura, 2004; Rose, 2006). This is happening in many Sub-Saharan African countries, with several states recently amending their statutory laws, and rights-based organisations taking various initiatives to improve equity in inheritance practice. Nevertheless, much remains to be done to address the links between inheritance rights and practices and poverty.

This Policy Note presents findings from a five country study commissioned by the Chronic Poverty Research Centre, which explored how inheritance is practiced to enhance or prevent socio-economic equity and opportunities. Policy Notes for Ghana, Kenya, Mozambique and Uganda, a working paper and a policy brief of key cross-cutting themes are available at: http://www.chronicpoverty.org/ publications/details/challenges-and-opportunitiesin-african-societies. Data were collected through interviews with representatives of governmental and non-governmental agencies working specifically on issues related to inheritance and property rights, as well as a review of research and policy literature.

Who is included and excluded from inheriting particular assets depends on legal property rights, as well as cultural norms concerning social roles and relationships. This Policy Note addresses how Rwandan law currently affects property inheritance, the challenges and opportunities in existing law reform, and the issues surrounding how inheritance is governed and practiced in people's lives in Rwanda.

\section{Box 1: Background on Rwanda}

Rwanda is the most densely populated country in Africa with a population of nearly 10.5 million people. The country was colonised by Germany and then Belgium until 1962. Conflict between Rwanda's two main ethnic groups (Hutus and Tutsis) broke out in 1959 displacing hundreds of thousands of mainly Tutsi people. Civil war and genocide between 1990 and 1994 killed over one million (Tutsis and moderate Hutus) and forcibly displaced millions of others within and beyond Rwandan borders. The first post-genocide elections were held in 2003 and a new constitution was passed by referendum. Former Tutsi militia leader Paul Kagame has remained Rwanda's President since 2000. World Bank indicators show that political stability and government effectiveness steadily improved between 2002 and 2007. Legislative reform has been a priority, which is lauded by international development and governments as progressive, particularly in terms of affirmative action for women. Rwanda receives substantial development aid and obtained IMF-World Bank Heavily Indebted Poor Country (HIPC) debt relief in 2006. The country's 2020 Vision promotes the agenda of moving 50 percent of the Rwandan population from reliance on land-based agriculture as their primary means of livelihood into other economic sectors, however progress to date on developing other sectors (e.g. high tech) has been minimal.

\section{Opportunities and challenges in policy}

Since 1994, the Rwandan government has pursued an ambitious law reform agenda, which has been supported by international governments such as the UK Department for International Development (DFID) and the United States Agency for International Development (USAID). Several proposed laws are in the works, including one to address genderbased violence, which may contain the country's first recognition of the property rights of cohabiting partners. However, while the Rwandan government is often praised for its gender initiatives, a recent labour law has been criticised to marginalise women. As well, a 1913 law which prohibits a married woman from making a business of commerce without the consent of her husband is still in the books.

In many other African countries, statutory law often clashes with customary law - with the latter prevailing, especially over land issues and among many rural populations. However, customary land tenure in Rwanda holds a different meaning and is a less significant practice than, for instance, in Kenya, Uganda, Ghana and Mozambique. Due to a history of centralised governance (during precolonial Rwanda and during the German and Belgian periods), migrations within, in and out of the country, and consequent changes in land holdings, Rwandan 
populations do not experience the same intensity and diversity of cultural and regional governance of lands. The small size of the country and the firm grip of the national government contribute to increasing consistency and transparency among local governing structures, rules and processes.

\section{Constitution of Rwanda}

The Constitution of Rwanda, adopted in 2003, makes clear the equal rights of Rwandan women and men. However, the Constitution contains that 'only civil [i.e. registered] monogamous marriage between a man and a woman is recognized'. This means that most adult women in Rwanda (who are not in registered marriages but in consensual cohabiting relationships) do not have equal protection of their property and inheritance rights under Rwanda's laws.

The Constitution can provide practical relevance for property and inheritance rights through the requirement that 30 percent of all governmental decision-making bodies should be composed of women. This applies to both local land administration and dispute resolution bodies which may be the first approach for individuals who seek to claim their rights.

\section{Intestate Succession and Marital Property Law}

Rwanda's 1999 Law on Inheritance and Marital Property Rights ${ }^{1}$ provides opportunities for gender equity by granting equal inheritance rights to sons and daughters ${ }^{2}$ and protecting surviving spouses' and children's rights to property. During marriage, property rights legislation outlines that the written and registered consent of both spouses is required for transactions such as the sale, donation, exchange, mortgage, or long term lease of land. This consent is valid for up to six months after the transaction; if not obtained, the transaction is not final until five years have passed without an affirmative objection from the spouse. This creates an important incentive for any potential buyer or mortgage lender to ensure that consent of the spouse is obtained. The law also states that if a couple divorces, property should be equally divided between them.

These stipulations set precedents for spouses' inheritance rights to property. According to the inheritance law, a surviving spouse married under the community of property marriage regime ${ }^{3}$ inherits all property as long as s/he provides assistance to the 'needy parents' of the deceased. If the surviving spouse remarries s/he is to keep only half of the original inherited property with the other half shared equally among the deceased's (legitimate and illegitimate) children. However, if a spouse remarries with children from a deceased partner, s/he retains one quarter of property in full ownership and threequarters is administered for the children. If both husband and wife die, their children are supposed to inherit their property.

The Law on Inheritance has thorough regulations to ensure that there is order and fairness of process when a property owner dies:

- First, an inventory of property for inheritance is to be done on the day of death.

- 'Immediately', a 'Council of Succession' is to be established, which includes the surviving spouse, a delegated child of the deceased of majority age, a delegate of the deceased's family, a delegate of the surviving spouse's family, a friend of the deceased and a friend of the surviving spouse.

- A 'Family Council' is also to be set up to determine how some heritable property will be earmarked for raising minor children, while other property will be equally shared among the deceased's children who have reached majority age. Allowing some flexibility, oral testimonies are considered during disputes that are taken to courts, if done in the presence of all or some of the rightful heirs and two additional witnesses.

- In such cases where a plot of land cannot be divided (partition of less than one hectare is not allowed under the Land Law), the Inheritance and Marital Property Law instructs that agreement must be reached on other ways of providing equal values of inheritance to all heirs. This opens the way for sale of heritable land or shared use of the land, and in both cases, division of proceeds.

The law also includes sanctions against neglect of the deceased during illness, and of the deceased's dependants or relatives afterwards. An individual can be excluded from inheriting if $s /$ he deliberately broke off a relationship with the deceased or deliberately neglected care during a deceased person's illness. As well, if the surviving (not remarried) spouse is found to neglect care of the deceased's children, threequarters of the inherited property will be redistributed to the children. 
This law rigorously outlines expectations and procedures which may be used as a blueprint for action. But its application requires significant awareness and commitment from many actors, which may not exist. There are also major limitations to this law. Most significantly, it applies only to registered legal marriages, which are not common in Rwanda, and excludes cohabiting and polygamous unions. For instance, upon the death of a man who had one legal marriage and other cohabiting 'wives', the wife and children of the legal marriage would have rights to a larger portion of the heritable estate. However, even widows of legally registered marriages have limited rights to the use of their matrimonial house and its furniture: a surviving spouse is not permitted to sell, mortgage or exchange the property, and if she is judged to be damaging the property, the Council of Succession can take it from her.

There is some confusion over whether ancestral land becomes marital community property or not. In practice, the law has often been interpreted to restrict widows' land inheritance rights (e.g. widows inherit as land managers or trustees rather than owners). ${ }^{4}$ The current wording of the Inheritance and Marital Property Law anticipates directions concerning land inheritance in forthcoming land regulations. To this end, Rwanda's 2005 land law, discussed below, simply states that land is inheritable.

Under the law, orphaned children's heritable property rights are required to be protected by an appointed guardian until children reach the age of majority (21 years in Rwanda); however, neglect and abuse of these provisions have been reported (Rose, 2005). To prevent such violations, public awareness, legal aid and enforcement of the existing law is required. Additionally, it is necessary to expand the legal concept of 'guardianship'; for example, to make it possible for the courts to grant 'active legal capacity' to minors on the basis of their mental maturity, their interest in becoming independent and in asserting their land rights; and to amend the requirement that orphans must obtain 'consent' in order to be legally emancipated from their guardians (see Rose, 2005).

\section{Land Law}

The so-called Organic Land Law ${ }^{5}$, passed in 2005 , establishes the framework for land rights in Rwanda, however, its implementation must still be laid out in forthcoming laws and regulations. Significant stipulations include that land is ultimately owned by the state, but individuals can hold long-term, secure rights to use it (i.e. long-term leases that can be sold, purchased, mortgaged, sub-leased, etc.), and that women and men have equal rights to land. Its agenda to adjudicate and register all land rights aims to resolve uncertainty over multiple land claims caused by past conflicts and migrations, and encourage the consolidation of small land holdings (within which are parcels of land registered to different people) to increase agricultural productivity. ${ }^{6}$ In fact, the law states that if land is not protected (e.g. against degradation) or used productively, it may be temporarily or permanently appropriated by the government. The law also requires that major land administration functions, such as registration and land use management, are decentralised to district, municipal and village levels with both women and men staffing these bodies.

Setting a precedent for land inheritance rights, the Land Law requires that all land transactions should have prior consent, as evidenced in signed (or fingerprinted) and witnessed documents, of all members of the family who hold rights in the land. These include legally married spouses, children who have reached majority age and minors represented by their guardians or incompetent children represented by their tutors. The enduring challenge for legally protecting most adult women's land rights is found in the lack of requirement for obtaining the consent of non-married partners prior to land transfers.

There is also a piece of secondary legislation, passed in 2008, which provides the means for a woman to be registered as the sole named landowner of a holding, potentially with her male partner registered as a holder of interest in the land. This provision was intended to offer an opportunity to establish legal property protection for second and subsequent wives in polygamous marriages who do not have land rights through their unions. However, uptake of this provision has been minimal and there is little monitoring and evaluation of how or why. 


\section{Opportunities and challenges in practice}

The relevance of statutory law in people's lives, and specifically in the realisation of inheritance rights, is often stymied by issues of access in other African countries, which is also the case in Rwanda, but not to the same detrimental degrees. The small size of the country and the relatively undisputed authority of the government, have supported the decentralisation of knowledge and services as well as the consistency and transparency of processes.

\section{Land registration}

Land registration processes are underway in Rwanda. These involve young local people walking the land with occupants and marking boundaries on maps. If disputes arise during the process, these are recorded on the Disputes Registrar and transferred to arbitration. A holding is only registered by the local land commission under the Claims Registrar if arbitration is resolved. Registration records are available for the public to review.

The National Land Centre (NLC), which is charged with land registration in Rwanda, has found that the processes involved in land registration often provoke inheritance disputes that are difficult to negotiate. In addition, the process has encountered situations that are not addressed by current legislation, for instance, those that pertain to property rights of unmarried cohabiting partners. For example, during pilot initiatives of land titling, the NLC experienced lack of policy guidance on how to account for the land rights of cohabiting couples. In response, in some cases, the NLC has used the existence of children between partners as their working definition for determining whether or not to register cohabiting spouses as individuals with interest rights in land. In other situations, the NLC has registered the rights of the children to land (i.e. for their prior consent before any transfer), but not the rights of unmarried, cohabiting mothers of these children, thereby operating on the assumption that the children's rights will protect a mother's rights. Such de facto policy making is so far without basis in any legislation.

\section{Rights awareness}

While the land registration process is likely to provide increased protection for women in (or widowed from) registered marriages, the property rights of unmarried women (during or after their unions) are insecure. The Rwandan government has organised campaigns to encourage legal marriages and there have been organised marriage ceremonies for large numbers of couples to make the costs of marriage less burdensome. Nevertheless, resistance persists and the majority of marriages are not registered.

Some Rwandan NGOs, including Haguruka, which focuses on women's and children's rights, and the Rwanda Women's Network, have been active in trying to raise awareness of Rwandan people's rights under the law by training paralegals and holding public education sessions. However, lack of adequate financial support has limited NGOs outreach. Haguruka, for instance, has trained 388 volunteer paralegals to serve throughout the country, but as all are volunteers, they cannot contribute sufficient time and travel to their cases. As well, such services are not located in offices, but in people's homes and out of their own initiatives.

\section{Dispute resolution}

Local mediation and dispute resolution bodies throughout Rwanda offer mediation processes; for example, the 'wachacha courts', which operate under the auspices of local land committees. These courts have been structured to involve local people, and guard against corruption by preventing disputing parties from knowing in advance who will be elected to hear their case. Less formally, village level governance has committees for women's affairs, economic affairs, etc., and 'Neighbour's Eye' meetings (held monthly following a community clean-up exercise) provide a forum to discuss personal issues. These bodies, however, are reported to operate with less than ideal knowledge of the law and favour customary practices and local power politics. Nevertheless, they provide logical opportunities for increasing public and local leaders' knowledge and participation in upholding community members' inheritance rights. Pursuing local disputes over property access remains difficult for women because of the social stigma they may provoke, as well as negative reactions from family members, including in-laws. However, more recent cases of women pursuing disputes may set important precedents (RISD, 2006).

As is common among decentralisation efforts in other countries (e.g. Ghana, Kenya, Mozambique and Uganda), Rwanda's decentralised administrative and alternative dispute resolution (ADR) bodies are 
widely acknowledged to be under-resourced. For example, local and national land committee members who oversee land titling processes are volunteers, and not all district land commissions are trained with basic knowledge of the laws. While the National Land Commission is supposed to do an annual report with recommendations for reforms of land processes, their volunteers (often with other full-time paying jobs) find they cannot afford the time to do such reporting. However, with such organisational structures already in place, efforts can be directed to improve the dissemination of knowledge and practice of the law. For instance, as a key informant described, since the existing law on inheritance provides fair inheritance settlements for (married) wives and all children, the need for writing wills is diminished - so long as the law's provisions are upheld.

Enforcement as a follow-up to dispute resolution and in favour of women's property rights remains a challenge throughout Rwanda. Investments in capacity building among the police are important to ensure peaceful enforcement of resolutions of inheritance cases. Ideally, recourse to the police would be exceptions to the extended and understood rules laid out in the law governing intestate succession.
Corruption can be crippling to decentralised services. The Rwandan government's initiatives against corruption (e.g. monitoring and the widely published Ombusman's report on corruption) are believed to be effective in curbing corruption as these address every administrative level, including local land commissions (e.g. in the 2009 Ombudsman's report, land officers were put on notice). Nevertheless, opportunities for corruption exist. For example, district land commissions currently report to both political heads of districts and the National Land Centre (NLC). The risk here is that land commissions can be used by local political leaders for their own advantage. To address this, the NLC would like control of the land titling process centralised so that land commissions are answerable only to the NLC. This is proposed to be a temporary process (e.g. three years) that may be ended once all land is initially registered.

To date, many donors ${ }^{7}$ have been reluctant to invest in land reform initiatives. Rwandan civil society actors believe there is not enough support for their work in engaging with the ongoing land registration process.

\section{Ways forward}

Rwanda's administrative and governance structures are generally well regarded for recognising equitable property and inheritance rights among men, women and children. The law governing inheritance and marital property rights outlines fair and transparent processes for the distribution of the property of a person who died without a will. The land law unequivocally states that husbands and wives have equal rights to land, and that consent is required by both prior to any land transactions. Recent pilot exercises for land titling have seemed to proceed in a participatory and flexible manner to accommodate the rights and interests of different people to the same land, and to refer potential inheritance disputes to local bodies for mediation. However, in all of this, systematic monitoring, evaluation and reporting is needed to ascertain the outcomes pertaining to gender equity as well as use of the land. For example, it is not yet known if the rule against subdivision of land plots of less than one hectare results in more people moving off the land and into other economic ventures, or whether different approaches to collective land management are emerging, and how these different outcomes are affecting people's livelihoods.

As a result of the lack of recognition of cohabiting unions and polygamous marriages, there are significant gaps that currently exist in statutory and practical protection of people's inheritance rights in Rwanda. As encountered during recent land registration processes, there is no legal basis to assert the rights of unmarried individuals (usually women) to property that is, in practice, shared. There is also no recognition that a person's contributions to a household and livelihood (e.g. financial and/or inkind through domestic work) can secure their rights to the physical property of that household or livelihood. Since the vast majority of Rwandan women live in unions that have not been registered as marriages, this is a major oversight of the realities of most Rwandan women. While the Rwandan government has encouraged Rwandans to legally marry, it would do well to legally recognise economic rights incurred by a cohabiting partner.

In recent years, the Rwandan government has taken steps to make access to administrative services easier and fairer for Rwandans. Services have been 
decentralised with structures clearly laid out, and ending corruption has been targeted at every level. Despite these gains, decentralised bodies remain under-resourced and knowledge of the laws among the public and local leaders has not adequately occurred. Investments in these initiatives, as well as those of civil society watchdogs, will be important to ensuring the processes, and not just the structures, are right.

This policy note was written by Elizabeth Cooper

\section{Notes}

1 Full Name: 12/11/1999 LAW N 22/99 O To Supplement Book I of the Civil Code and to Institute Part Five Regarding Matrimonial Regimes, Liberalities and Successions. O.G. N²2 OF 15/11/1999).

2 This law also states that no distinction can be made between girls and boys when living parents distribute their property among their children.

3 Under this law, spouses choose at the time of marriage which of three matrimonial regimes will govern their marital property and inheritance rights: 1) community of property (joint ownership of all property); 2) limited community of acquests (property is inventoried to be either owned jointly or separately by spouses as outlined in a contract); or 3) separation of property (each spouse retains personal property and agrees by contract to contribute a proportion to household expenses). Under marriages with separation of property, the deceased's property devolves first to the deceased's children, and then to the deceased's parents and other lineage relations, before consideration of the surviving spouse.

4 Disconcertingly, an RISD review (2006) found the Kinyarwanda language version the Inheritance and Marital Property Law states that the surviving spouse is not an heir to ancestral land, but rather a manager of such property on behalf of the children or other heirs. The English version seems to clearly state that all property acquired becomes part of the community property and that women therefore would have the right to ancestral land on the same terms as any other community property. In the English version of the Land Law it reads that the land is equally owned by the 'wife and husband' whereas the French version translates back into English as 'man and woman'. These are important discrepancies to be resolved.

5 Full Name: 14/07/2005 Organic Law Nº8/2005 Determining the Use and Management of Land in Rwanda (O.G. No18 OF 15/09/2005).

6 The process of land consolidation is organised under the Ministry of Agriculture, which is currently drafting a relevant law. According to some key informants, the simultaneous processes of land titling and land consolidation have confused some Rwandans. In some cases people have been asked to consolidate plots before land titling has occurred thereby undermining the sense of security land titling is supposed to yield.

7 This excludes for instance, the UK DFID, which is continuing to support work on the implementation of Rwanda's land tenure reform programme.

\section{References}

Benschop, M. and Sait, M. (2006). 'Progress Report on Removing Discrimination Against Women in Respect of Property and Inheritance Rights'. Nairobi: United Nations Human Settlements Programme. Available at: www.unhabitat.org/downloads/ docs/3983 71713 Inheritance percent20Final percent20071006.pdf

Bird, K. and Pratt, N. with O'Neil, T. and Bolt, V. (2004). 'Fracture Points in Social Policies for Chronic Poverty Reduction'. Chronic Poverty Research Centre Working Paper 47, Overseas Development Institute Working Paper 242. London: Overseas Development Institute (ODI) and Chronic Poverty Research Centre (CPRC). Available at: http://www.chronicpoverty.org/ uploads/publication files/WP47 Bird et al.pdf

Cooper, E. (2008). 'Inheritance Practices and the Intergenerational Transmission of Poverty: A Literature Review and Annotated Bibliography'. Chronic Poverty Research Centre Working Paper 116. Manchester, UK: Chronic Poverty Research Centre (CPRC). Available at: http://www.chronicpoverty.org/uploads/publication_files/WP116 Cooper-annotatedbib-litreview.pdf

Cooper, E. (2010). 'Inheritance and the Intergenerational Transmission of Poverty in Africa: Policy Considerations'. Chronic Poverty Research Centre working Paper 159. Manchester, UK: Chronic Poverty Research Centre (CPRC). Available at: http:// www.chronicpoverty.org/uploads/publication files/WP159\%20Cooper.pdf

Daley, E. (2009). Women's Land Rights in Rwanda. Presentation at Securing Women's Land Rights in Africa, Notes of a Royal Africa Society meeting, January 29 2009. Available at: http://www.oxfam.org.uk/resources/learning/landrights/downloads/ securing_wir_in_africa_ras_mtg_29_jan_09.pdf

Davies, P. (2005). 'Marriage, Divorce and Inheritance Laws in Sierra Leone and their Discriminatory Effects on Women'. Human Rights Brief, 12 (3), 17-20.

Fafchamps, M. and Quisumbing, A. (2005). 'Assets at Marriage in Rural Ethiopia'. Journal of Development Economics, 77, 125.

Human Rights Watch (2003). Double Standards: Women's Property Rights Violations in Kenya. New York: Human Rights Watch. Available at: http://www.hrw.org 
Mutangadura, G. (2004). 'Women and Land Tenure Rights in Southern Africa: A Human Rights-based Approach'. Presentation at Land in Africa: Market Asset or Secure Livelihood Conference, London, UK, November 8-9, 2004. Available at: http://pubs.iied.org/pdfs/ G00173.pdf

Rose, L. (2005). 'Orphans' Land Rights in Post-War Rwanda: The Problem of Guardianship'. Development and Change, 36 (5), 911 936. Sabates-Wheeler, R. (2006). 'Asset Inequality and Agricultural Growth: How Are Patterns of Asset Inequality Established and Reproduced?'. Washington, DC: World Bank. Available at: http://siteresources.worldbank.org/INTRANETSOCIALDEVELOPMENT/ Resources/AgriclnequalityRachelSabatesWheeler.pdf

Rose, L. (2006). 'Children's Property and Inheritance Rights and their Livelihoods: The Context of HIV and AIDS in Southern and East Africa'. Food and Agricultural Organization of the United Nations. Available at: www.oxfam.org.uk/resources/learning/landrights/ downloads/childrens_property_and_inheritance_rights_and_livelihoods.pdf

Strickland, R. (2004). 'To Have and To Hold: Women's Property and Inheritance Rights in the Context of HIV/AIDS in Sub-Saharan Africa'. Washington, DC: International Center for Research on Women. Available at: www.icrw.org/docs/2004_paper_haveandhold. $\underline{\mathrm{pdf}}$ 